\title{
ANALISIS DESAIN KEMASAN YOGURT DRINK 'CIMORY'
}

\author{
Analysis of 'Cimory' Yogurt Drink Packaging \\ Shierly Everlin" ${ }^{* 1}$, Catherine Yosephine ${ }^{2}$ \\ ${ }^{1}$ Program Studi Desain Komunikasi Visual, Universitas Bunda Mulia \\ Diterima: 5 Oktober 2018/Disetujui: 12 Oktober 2018
}

\begin{abstract}
The appeal of a product is certainly inseparable from the packaging design of a product. The design of a package is the main identity that distinguishes a product from other similar products. The purpose of this research is to analyze the packaging design of Cimory Yogurt Drink using visual attractiveness and practical appeal theory. This research uses qualitative method which delivers descriptive data of packaging design and its information which is aligned with visual theories and literatures. The output of this research is the visual analysis of each packaging of Cimory Yogurt Drink which aims to be the academic reference for designers and the related industries who will make similar products.
\end{abstract}

Keywords: Packaging, Yogurt, Yogurt Drink, Cimory.

\begin{abstract}
ABSTRAK
Daya tarik sebuah produk tentunya tidak terlepas dari desain kemasan sebuah produk. Desain dari sebuah kemasan merupakan identitas utama yang membedakan sebuah produk dengan produk sejenis lainnya. Penelitian ini dilakukan untuk menganalisis desain kemasan dari Cimory Yogurt Drink menggunakan teori daya tarik visual dan daya tarik praktis. Penelitian ini menggunakan metode kualitatif yang memberikan data deskriptif desain kemasan dan informasinya yang selaras dengan teori dan literatur visual yang digunakan. Hasil penelitian ini adalah analisis visual setiap kemasan Cimory Yogurt Drink sebagai referensi akademik yang dapat berguna bagi para desainer dan pebisnis yang akan membuat produk yang serupa.
\end{abstract}

Keywords: Kemasan, Yogurt, Yogurt Drink, Cimory.

\section{PENDAHULUAN}

Yogurt adalah salah satu jenis susu dengan tipe proses susu fermentasi dimana metode ini merupakan metode tertua dalam jangka waktu penyimpanan susu, dan sudah dipraktekkan dalam kehidupan manusia sejak ribuan tahun yang lalu. Komposisi kimia dari susu fermentasi memberikan indikasi yang berguna tentang nilai gizi produk ini. Komponen utama susu fermentasi ini adalah protein, lemak, karbohidrat, mineral dan vitamin. Manfaat kesehatan dari produk ini dan kegunaan dari produk ini digunakan sebagai pengobatan sejak beberapa ribu tahun yang lalu. Produk ini disebut sebagai obat untuk menyembuhkan gangguan metabolisme perut dan usus, oleh ilmuwan kuno (Oberman \& Libudzisz, 1998).

Yogurt yang kita kenal sekarang ini memiliki sejarah yang sangat panjang. Yogurt mengandung bakteri hidup sebagai probiotik, yaitu mikroba dari makanan yang menguntungkan bagi microflora di dalam saluran pencernaan. Sejauh ini jenis probiotik yang paling umum adalah bakteri asam laktat dari golongan Lactobacillus bulgaricus, Streptococcus themophillus dan Lactobacillus casei.

Yogurt adalah minuman yang baik bagi kesehatan. Walaupun sejarahnya di Indonesia tidak begitu jelas, namun dari data Badan Pusat Statistik (BPS) mengungkapkan bahwa adanya peningkatan impor yogurt di Indonesia sejak tahun 2004

\footnotetext{
*email: severlin@bundamulia.ac.id
} 
sampai dengan 2008 yang menandakan bahwa masyarakat Indonesia semakin sadar untuk meningkatkan gaya hidup sehat. Mulai meningkatnya gaya hidup sehat di Indonesia dengan mengonsumsi yogurt juga membuat Indonesia memiliki beberapa merek yogurt lokal buatan Indonesia yang telah ada di pasaran, seperti Cimory, Heavenly Blush, Yummy, Biokul dan lainnya.

Cimory atau Cisarua Mountain Dairy adalah salah satu perusahaan lokal yang menjual produk susu beserta dengan olahannya seperti yogurt, keju, krim keju dan kue. Cimory (PT Cisarua Mountain Dairy) adalah salah satu produsen susu lokal paling terkenal di Indonesia. Industri pengolahan susu (IPS) yang didirikan tahun 2006 ini terletak di pegunungan Cisarua, Puncak, Jawa Barat. Produk yogurt Cimory terdiri dari minuman aneka rasa serta yogurt cup. Selain yogurt, Cimory juga menjual susu pasteurisasi, keju dan roti.

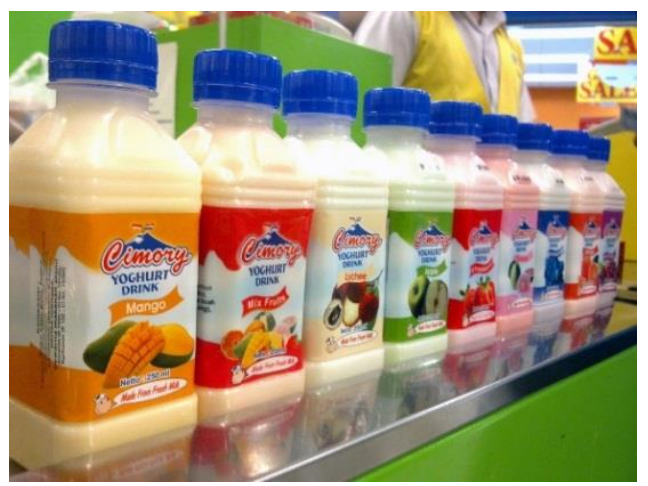

Gambar 1 Kemasan Yogurt Drink

(Sumber: Data Internet, 2018)

Yogurt Drink Cimory pada
awalnya menggunakan kemasan botol
plastik ukuran $250 \mathrm{ml}$ dengan tutup botol
berwarna biru. Pada produk Yogurt Drink
ini terdapat 9 varian rasa.

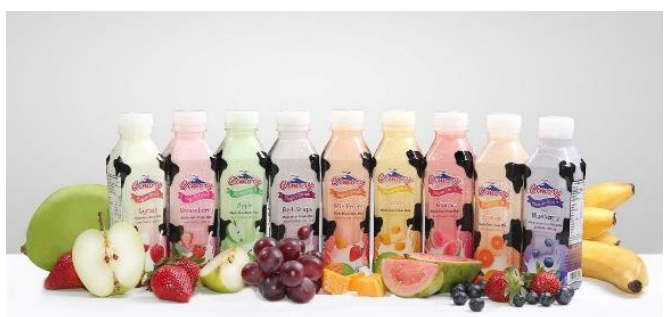

Gambar 2 Kemasan Yogurt Drink Cimory Saat ini

(Sumber: Data Internet, 2018)

Kemasan Yogurt Drink Cimory saat ini tetap mengunakan botol plastik dengan ukuran $250 \mathrm{ml}$ namun tampilannya menjadi lebih menarik dibandingkan dengan kemasan terdahulu. Dengan kemasan yang ada saat ini, produk Yogurt Drink Cimory sudah dikembangkan menjadi 11 varian rasa.

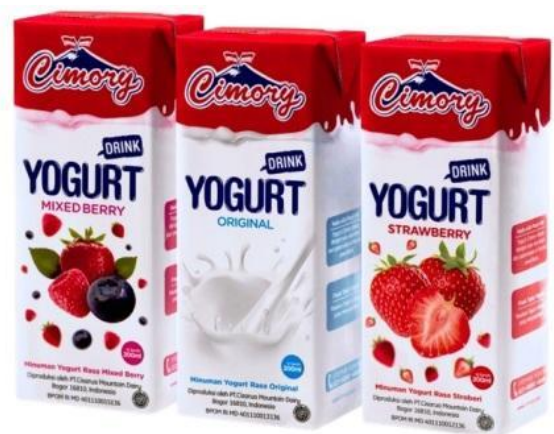

Gambar 3 Kemasan Yogurt Drink 200 ml (Sumber: Data Internet, 2018)

Kemudian pada tahun 2015 Cimory mengeluarkan jenis produk Yogurt Drink yang lain, yaitu kemasan $200 \mathrm{ml}$ dengan menggunakan bahan tetrapak. Terdapat 3 varian rasa dalam produk ini. 


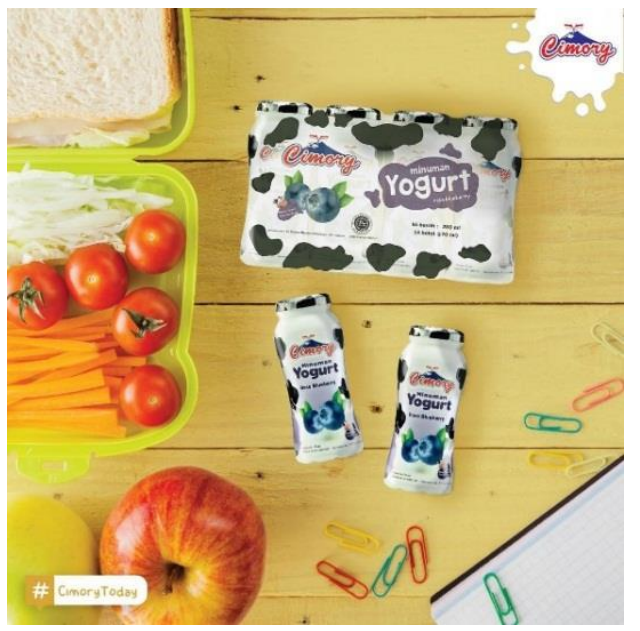

Gambar 4 Yogurt Mini 70 ml

(Sumber: Data Internet, 2018)

Pada Mei 2017 Cimory kembali memberikan tampilan baru kemasan yogurt drink dengan ukuran yang lebih kecil yaitu $70 \mathrm{ml}$ yang terdapat 4 botol dalam 1 pack. Pada produk Yogurt mini ini terdapat 4 varian rasa. Namun terdapat perbedaan komposisi antara yogurt drink dan yogurt mini. Di dalam komposisi yogurt mini terdapat susu skim dan susu segar, sedangkan pada produk yogurt drink 250 $\mathrm{ml}$ dan $200 \mathrm{ml}$ hanya terdapat susu segar.

Inovasi seperti ini ditujukan untuk menarik perhatian pasar dan ingin bertahan di dalam persaingan industri dengan produk yang serupa. Tujuan utama strategi bersaing untuk sebuah unit bisnis dalam sebuah industri adalah menemukan posisi dalam industri tersebut dimana perusahaan dapat melindungi diri sendiri dengan sebaikbaiknya.

Tujuan dan manfaat dari penelitian ini adalah untuk menganalisis desain kemasan produk Yogurt Drink Cimory dengan pendekatan teori daya tarik visual dan daya tarik praktis. Adapun manfaat dari penelitian ini adalah untuk meningkatkan kualitas desain kemasan produk dalam negeri.

\section{KAJIAN PUSTAKA}

\section{Teori Kemasan}

Menurut Sri Julianti dalam buku

"The Art of Packaging" (2014:15) mengatakan bahwa kemasan adalah wadah untuk meningkatkan nilai dan fungsi sebuah produk.

Giles Calver dalam bukunya yang berjudul "What is Packaging Design?" (2007:6) mengatakan bahwa kemasan muncul pada abad ke-19 karena teknologi baru yang memungkinkan produsen dan petani memasok produk mereka ke dalam kemasan dalam kemasan pra-paket. Untuk pertama kalinya, teknologi ini membantu petani menghasilkan produk mereka, mengemasinya selagi segar dan mengangkutnya ke pasar. Dengan kata lain produsen produk dapat mengemas produk dengan cara yang menarik agar dapat dijual oleh pedagang.

\section{Fungsi Kemasan}

Sri Julianti dalam buku "The Art of Packaging" (2014:15) juga mengatakan bahwa kemasan juga harus memiliki fungsi strategis yang sifatnya mampu memberikan positioning baru dan leverage atau daya ungkit bagi sebuah produk. Berdasarkan fungsinya, kemasan dibagi menjadi dua, yaitu:

a. Kemasan primer

Kemasan primer adalah keseluruhan kemasan yang dipajang dan yang membuat konsumen memutuskan untuk membeli produk tersebut. Kemasan primer sangat penting dari segi fungsinya untuk melindungi (protection), komunikasi ke pelanggan (communication) dan termasuk fungsi artistik agar konsumen yang melihat langsung tertarik untuk membeli produk tersebut.

b. Kemasan sekunder

Kemasan sekunder atau yang disebut dengan transport packaging diperlukan untuk melindungi kemasan primer selama dalam penyimpanan di gudang serta saat didistribusikan ke pelanggan partai besar maupun pelanggan eceran. Kemasan sekunder merupakan satu 
kemasan dengan kemasan primer. Pada kemasan primer yang menggunakan bahan fleksibel, sering kali diperlukan kemasan sekunder yang lebih kuat untuk melindungi produk maupun kemasan primernya.

Berdasarkan material atau bahan bakunya, kemasan juga dapat dibagi menjadi beberapa macam, seperti:

- Natural/alam: daun, bambu dan kayu.

- Kertas dan karton, termasuk karton gelombang.

- Plastik dan rigid dan semi-rigid.

- Fleksibel.

- Gelas.

- Logam: aluminium dan baja.

\section{Prinsip Dasar Kemasan}

Ada banyak variabel yang memengaruhi bagaimana dan mengapa desain kemasan menarik konsumen. Periset konsumen menghabiskan waktu yang banyak untuk menganalisi variabel-variabel ini. Dari suatu perspektif desain murni (memindahkan variabel pemasaran lain seperti harga, lokasi, dan kesetiaan merek) terdapat elemen-elemen penting yang menangkap perhatian konsumen dengan sangat baik dan menerobos kerumunan visual dalam kompetisi ritel. (Klimchuk \& Krasovec, 2007:82)

Empat penarik perhatian utama suatu kemasan adalah:

1. Warna.

2. Struktur fisik atau bentuk.

3. Simbol dan angka.

4. Tipografi.

\section{Daya Tarik Kemasan}

Daya tarik kemasan dapat digolongkan menjadi 2 (dua), yaitu:

a. Daya Tarik Visual (Estetika)

Daya tarik visual mengacu pada penampilan kemasan yang mencakup unsur grafis (warna, bentuk, merek/logo, ilustrasi, huruf/tipografi, tata letak). Semua unsur grafis tersebut dikombinasikan untuk menicptakan suatu kesan untuk memberikan daya tarik visual secara optimal. Daya tarik visual sendiri berhubungan dengan faktor emosi dan psikologis.

b. Daya Tarik Praktis (fungsional)

Daya tarik praktis merupakan efektifitas dan efisiensi suatu kemasan yang ditujukan kepada konsumen maupun distributor, misalnya untuk kemudahan penyimpanan atau pemajangan produk. Faktor-faktor yang berkaitan dengan daya tarik praktis (fungsional) adalah sebagai berikut:

1. Faktor Pengamanan

Kemasan harus melindungi produk terhadap berbagai kemungkinan yang dapat menjadi penyebab timbulnya kerusakan barang, misalnya: cuaca, sinar matahari, jatuh, tumpukan, kuman, serangga dan lain-lain. Contohnya, kemasan biskuit yang dapat ditutup kembali agar kerenyahannya tahan lama.

2. Faktor Ekonomi

Perhitungan biaya produksi yang efektif termasuk pemilihan bahan, sehingga biaya tidak melebihi proporsi manfaatnya. Contohnya, produk-produk re-fill atau isi ulang, produk-produk susu atau makanan bayi dalam karton.

3. Faktor Pendistribusian

Kemasan harus mudah didistribusikan dari pabrik ke distributor atau pengecer sampai ke tangan konsumen. Di tingkat distributor, kemudahan penyimpanan dan pemajangan perlu dipertimbangkan. Bentuk dan ukuran kemasan harus direncanakan dan dirancang sedemikian rupa sehingga tidak sampai menyulitkan peletakan di rak atau tempat pemajangan.

4. Faktor Komunikasi

Kemasan sebagai media komunikasi menerangkan dan mencerminkan produk, citra merek, dan juga bagian dari produksi dengan pertimbangan mudah dilihat, dipahami dan diingat. Misalnya, karena bentuk kemasan yang aneh 
sehingga produk tidak dapat "diberdirikan", harus diletakkan pada posisi "tidur" sehingga ada tulisan yang tidak dapat terbaca dengan baik, maka fungsi kemasan sebagai media komunikasi sudah gagal.

5. Faktor Ergonomi

Pertimbangan agar kemasan mudah dibawa atau dipegang, dibuka dan mudah diambil sangatlah penting. Pertimbangan ini selain mempengaruhi bentuk dari kemasan itu sendiri juga mempengaruhi kenyamanan pemakai produk atau konsumen. Contohnya, bentuk botol minyak goreng Tropical yang pada bagian tengahnya diberi cekungan dan tekstur agar mudah dipegang dan tidak licin bila tangan pemakainya terkena minyak.

6. Faktor Identitas

Kemasan secara keseluruhan harus berbeda dengan kemasan lain, memiliki identitas produk agar mudah dikenali dan dibedakan dengan produk-produk yang lain.

7. Faktor Promosi

Kemasan mempunyai peranan penting dalam bidang promosi, dalam hal ini Kemasan berfungsi sebagai silent sales person. Peningkatan kemasan dapat efektif untuk menarik perhatian konsumen-konsumen baru.

Faktor Lingkungan

Kita hidup di dalam era industri dan masyarakat yang berpikiran kritis. Dalam situasi dan kondisi seperti ini, masalah lingkungan tidak dapat terlepas dari pantauan kita. Trend dalam masyarakat kita akhir-akhir ini adalah kekhawatiran mengenai polusi, salah satunya pembuangan sampah. Salah satunya yang pernah menjadi topik hangat adalah styrofoam. Pada tahun 1990 organisasi-organisasi lingkungan hidup berhasil menekan perusahaan Mc Donalds untuk mendaur ulang kemasan-kemasan mereka. (Cenadi,1999:8).

Warna

Linda Holtzschue dalam buku "Undestanding Color an Introduction for Designer" (2011:2) mengatakan bahwa warna itu merangsang, menenangkan, ekspresif, mengganggu, mengesankan, kultural, riang dan simbolik. Warna terdapat di seluruh aspek kehidupan kita, memperindah sesuatu yang terlihat biasa dan memberi kecantikan serta drama pada objek yang kita temu dalam kehidupan sehari-hari.

Romansa warna ada pada semua orang, tetapi warna memiliki aspek tambahan untuk seorang desainer profesional. Bentuk, warna dan susunannya merupakan elemen fondasi dari desain. Seorang yang ahli dalam warna mengerti apa itu warna, bagaimana warna itu terlihat, mengapa warna itu berubah, produk warna itu sendiri. Apapun produk yang ada, pewarnaan yang baik dapat menentukan keberhasilan atau kegagalannya di pasar konsumen.

Edith Anderson Feisner dalam "Color Studies. $\quad 2^{\text {nd }} \quad$ Edition" $\quad(2006: 20)$ mengatakan bahwa setiap warna memiliki 4 dimensi, yaitu:

a. Hue. Istilah untuk menunjukan nama dari suatu warna, seperti merah, biru, hijau dan warna lainnya.

b. Value. Dimensi kedua dari suatu warna yang berkaitan dengan terang gelapnya warna.

c. Intensity. Sering juga disebut chroma, adalah dimensi yang berhubungan dengan cerah atau suramnya warna.

d. Temperature. Dimensi yang berhubungan dengan panas dinginnya suatu warna.

Saat ini terdapat beberapa system warna yaitu, CMYK atau Process Color System, Munsell Color System, Ostwald Color System, Schopenhauer/Goethe Weighted Color System, Substractive Color System serta Additive Color/RGB 
Color System. Di antara bermacam sistem warna yang telah disebutkan, kini yang banyak dipergunakan dalam industru media visual cetak adalah CMYK atau Process Color System yang membagi warna dasarnya menjadi Cyan, Magenta, Yellow dan Black. Sedangkan RGB Color System dipergunakan dalam industri media visual elektronik.

\section{Ilustrasi}

Adi Kusrianto dari buku "Pengantar Desain Komunikasi Visual" (2007:33) mengatakan bahwa sebuah ilustrasi mampu membantu pembaca untuk menggambakan apa yang tertulis dalam suatu artikel, maupun cerita. Seorang ilustrator yang baik mampu berperan sebagai visualizer atas sebuah naskah. Ilustrasi adalah seni gambar yang dimanfaatkan untuk memberikan penjelasan atas suatu maksud atau tujuan secara visual. Dalam perkembangannya, ilustrasi tidak hanya berguna sebagai sarana pendukung cerita, tetapi juga dapat menghiasi ruang kosong. Seperti majalah, koran, tabloid, media iklan online, dan lain-lain. Ilustrasi mempunyi beberapa macam, seperti karya seni, sketsa, lukis, grafis, karikatural dan lain-lain. Seiring dengan berkembangnya teknologi terdapat ilustrasi dengan bentuk image, bitmap, vector, hingga karya foto.

Berikut adalah beberapa teknik ilustrasi yang digunakan pada desain media:

\section{a. Teknik Fotografi}

Ilustrasi berupa foto dihasilkan dengan teknik fotografi menggunakan kamera, baik manual maupun digital. foto yang dihasilkan kamera digital memungkinkan adanya pengolahan lebih lanjut tanpa scanning di komputer untuk memberikan ekspresi maupun ilustrasi tertentu sesuai keinginan.

b. Teknik Gabungan

Pujiriyanto dalam buku "Desain Grafis Komputer" (2005:42) mengatakan bahwa perpaduan struktur rupa antara hand drawing dengan teknik fotografi yang digabungkan dengan menggunakan komputer yang bertujuan untuk menyempurnakan kedua teknik tersebut.

c. Teknik Line Art

Line art adalah setiap gambar yang terdiri dari garis-garis lurus atau melengkung yang berbeda ditempatkan berlawanan dengan latar belakang yang polos tanpa adanya gradasi di tempat gelap berwarna untuk mewakili benda dua dimensi. Line art menekankan bentuk dan garis, warna, shading dan tekstur.

d. Teknik Flat Design

Flat design adalah desain dengan pendekatan minimalis yang menekankan kegunaan, dengan desain yang bersih tanpa ada bayangan, tekstur, berfokus pada tipografi, warna-warna cerah dan ilustrasi dua dimensi. Gambar sederhana menyampaikan pesan yang lebih cepat daripada ilustrasi yang sangat detail. Gambar seperti ikon dapat menunjukkan tindakan atau tujuan yang universal agar dapat mudah dimengerti.

Menurut Soedarso (2014:566) berdasarkan penampilannya, gambar ilustrasi memiliki berbagai jenis, yaitu:

a. Gambar Ilustrasi Naturalis yaitu gambar yang memiliki bentuk dan warna yang sama dengan kenyataan (realis) yang ada di alam tanpa adanya pengurangan ataupun penambahan.

b. Gambar Ilustrasi Dekoratif adalah gambar yang berfungsi untuk menghiasi sesuatu dengan bentuk yang disederhanakan atau dilebih-lebihkan (dibuat gaya tertentu sebagai style).

c. Gambar Kartun adalah gambar yang memiliki bentuk-bentuk yang lucu atau memiliki ciri khas tertentu. Biasanya gambar kartun banyak menghiasi majalah anak-anak, komik dan cerita bergambar.

d. Gambar Karikatur adalah gambar kritikan atau sindiran yang dalam penggambarannya telah mengalami penyimpangan bentuk proporsi tubuh. Gambar ini banyak ditemukan di majalah atau koran. 
e. Cerita Bergambar (Cergam) adalah sejenis komik atau gambar yang diberi teks. Teknik menggambar cergam dibuat berdasarkan cerita dengan berbagai sudut pandang penggambaran yang menarik.

f. Ilustrasi buku pelajaran mempunyai fungsi untuk menerangkan teks atau suatu keterangan peristiwa baik ilmiah maupun gambar bagian. Bentuknya bisa berupa foto, gambar natural, juga bisa berbentuk bagan.

g. Ilustrasi khayalan adalah gambar hasil olahan daya cipta secara imajinatif (khayal). Cara penggambaran seperti ini banyak ditemukan pada ilustrasi cerita, novel, roman dan komik.

\section{Metode Penelitian}

Penelitian ini menggunakan metode kualitatif dimana dilakukan analisis berdasarkan teori-teori yang terkait dengan sumber-sumber buku dan literatur terpercaya.

\section{HASIL DAN PEMBAHASAN}

Cimory selalu berkembang dari segi desain kemasan untuk menarik konsumen dari kemasan pertama sampai dengan kemasan yang ada pada saat ini.

Pembahasan analisis desain kemasan Yogurt Drink Cimory dilakukan berdasarkan teori daya tarik visual dan daya tarik praktis kemasan.

\section{Analisis Desain Kemasan Yogurt Drink Cimory}

\section{Kemasan Awal Yogurt Drink}

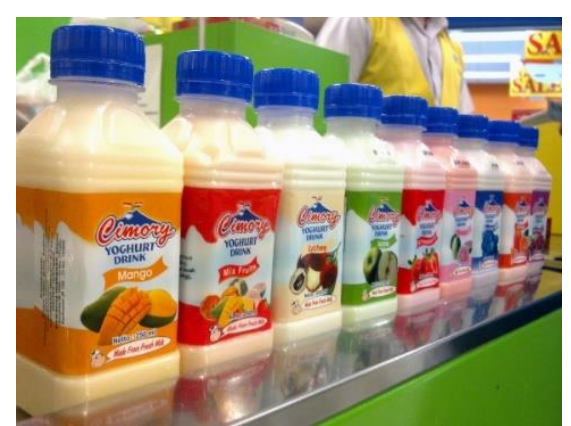

Gambar 5 Kemasan Yogurt Drink Pertama (Sumber: Data Internet, 2018)
1. Daya Tarik Visual

a. Warna

Terdapat beberapa warna yang digunakan pada kemasan. Warnawarna yang digunakan disesuaikan dengan varian rasa yang ada. Warna-warna yang digunakan juga merupakan warna-warna yang cerah. Sehingga dapat menarik perhatian konsumen.

b. Bentuk

Konsep kemasan Cimory adalah kemasan yang praktis dan mudah dibawa.

c. Logo

Logo yang terpampang pada kemasan adalah logo dari Cimory itu sendiri. Penempatan logo terdapat di tengah atas desain botol dengan warna logo berwarna merah sehingga mudah terbaca oleh konsumen.

d. Ilustrasi

Ilustrasi yang digunakan pada kemasan menggunakan teknik gabungan foto dan vector. Foto yang ditampilkan pada kemasan untuk memperjelas varian rasa yang ada pada kemasan. Ilustrasi vector berupa tekstur susu untuk memperjelas bahwa produk yang dijual adalah produk olahan susu.

e. Huruf/Tipografi

Tipografi yang digunakan pada kemasan ini adalah jenis san serif pada tulisan Yogurt Drink sehingga memiliki tingkat keterbacaan yang baik. Ukuran yang digunakan juga cukup baik.

f. Tata Letak

Kemasan sudah disertai dengan informasi yang lengkap dan cukup baik.

2. Daya Tarik Praktis

a. Faktor Pengaman

Kemasan yang digunakan cukup baik untuk melindungi isi produk. Kemasan yang digunakan terbuat dari plastik PET berukuran $250 \mathrm{ml}$. Tutup pada botol juga disertai segel 
sehingga cairan yang ada di dalam botol tidak bocor.

b. Faktor Ekonomi

Kemasan menggunakan botol plastik khusus minuman sekali pakai namun tetap ekonomis dalam perhitungan biaya produksi.

c. Faktor Distribusi

Kemasan yang digunakan memudahkan dalam pendistribusian produk. Kemasan dirancang untuk tidak menyulitkan peletakan di rak ataupun tempat pemajangan produk.

d. Faktor Komunikasi

Kemasan Cimory ini juga sudah cukup baik dari segi komunikasi. Kemasan cukup mencerminkan citra produk, mudah dipahami dan diingat oleh pelanggan.

e. Faktor Ergonomi

Kemasan memiliki faktor ergonomi yang baik. Kemasan memiliki ukuran yang mudah untuk dipegang, dibawa dan diambil. Selain itu kemasan juga cukup mudah untuk dibuka.

f. Faktor Identitas

Identitas produk dapat dengan mudah dikenali melalui kemasan. Warna yang digunakan cukup mencolok serta logo ditampilkan di bagian atas dengan ukuran yang cukup besar.

g. Faktor Promosi

Dari segi promosi, kemasan telah mempromosikan produk dengan baik. Menyertakan ilustrasi yang dapat membedakan varian rasa dengan jelas.

h. Faktor Lingkungan

Kemasan yang digunakan termasuk kemasan yang ramah lingkungan karena mudah terurai.

\section{Kemasan Yogurt Drink Versi Baru}

\begin{tabular}{|c|c|c|c|c|}
\hline \multicolumn{5}{|c|}{ Analisis Visual dan Daya Tarik Praktis Yogurt Drink Cimory } \\
\hline No & Elemen & Besar & Sedang & Kecil \\
\hline 1 & Produk & $250 \mathrm{ml}$ & $200 \mathrm{ml}$ & $70 \mathrm{ml}$ \\
\hline 2 & $\begin{array}{l}\text { Gambar } \\
\text { Produk }\end{array}$ & 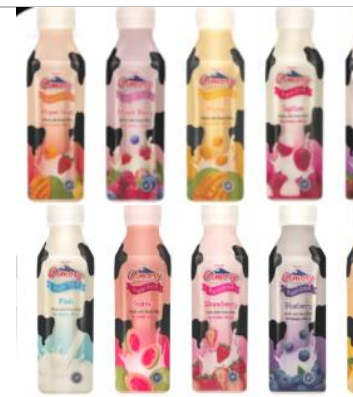 & 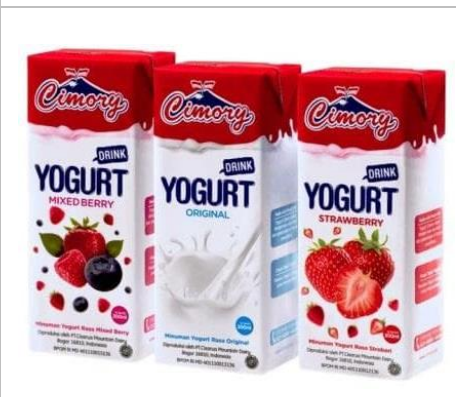 & 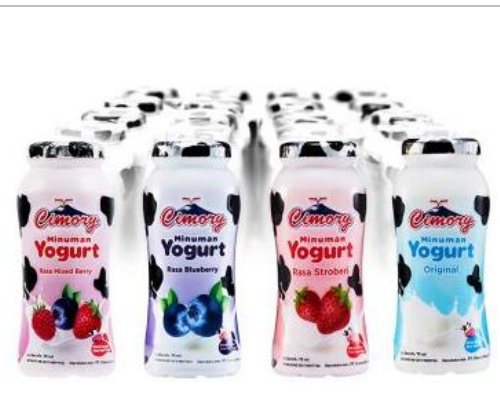 \\
\hline 3 & \multicolumn{4}{|c|}{ Fungsi Kemasan } \\
\hline & Primer & $\begin{array}{l}\text { - } \square \\
\text { - semi rigid - Plastik } \\
\text { PET (Polyethylene } \\
\text { Therepthalate) } \\
\text { - fleksibel - Plastik } \\
\text { pembungkus botol }\end{array}$ & $\begin{array}{l}\text { - } \square \\
\text { - } \text { semi rigid - Karton Tetra } \\
\text { Pak }\end{array}$ & $\begin{array}{ll}\text { - } & \square \\
\text { - } & \text { semi rigid - Plastik PS } \\
& \text { (Polistirena resin) } \\
\text { - } & \text { fleksibel - Plastik } \\
& \text { pembungkus botol }\end{array}$ \\
\hline & Sekunder & - & - & $\begin{array}{l}\text { - } \square \\
\text { - } \text { Fleksibel - Plastik } \\
\text { pembungkus paket } \\
\text { minuman yogurt (1 paket } 4 \\
\text { botol minuman } 70 \mathrm{ml})\end{array}$ \\
\hline
\end{tabular}




\section{Varian Rasa}

10 rasa:

Mixed Fruit, mixed berry, mango, lychee, red grape, original, blueberry, guava, strawberry, passion fruit

\section{Daya Tarik Visual (Estetika)}

\begin{tabular}{|c|c|c|c|}
\hline Warna & $\begin{array}{l}\text { warna sesuai varian rasa, } \\
\text { menggunakan warna } \\
\text { pastel dari warna } \\
\text { yogurtnya sendiri } \\
\text { sehingga secara } \\
\text { keseluruhan produk } \\
\text { terlihat lebih feminin }\end{array}$ & $\begin{array}{l}\text { warna sesuai varian rasa, } \\
\text { menggunakan dominan } \\
\text { warna merah dan putih }\end{array}$ & $\begin{array}{l}\text { warna disesuaikan dengan } \\
\text { varian rasa }\end{array}$ \\
\hline Bentuk & $\begin{array}{l}\text { lebih ramping dan lebih } \\
\text { mudah dipegang } \\
\text { (dibanding kemasan } 250 \\
\text { ml sebelumnya) }\end{array}$ & $\begin{array}{l}\text { kemasan kotak yang saat } \\
\text { ini umum dipakai oleh } \\
\text { sesama produk minuman } \\
\text { yogurt. Sederhana dan } \\
\text { memiliki ukuran yang pas } \\
\text { untuk digenggam. }\end{array}$ & $\begin{array}{l}\text { kemasan mini dengan lekukan } \\
\text { pada bagian tengah botol yang } \\
\text { memudahkan konsumen untuk } \\
\text { minum secara cepat dan tidak } \\
\text { mudah tersedak. }\end{array}$ \\
\hline Logo & $\begin{array}{l}\text { Logo yang terpampang } \\
\text { pada kemasan adalah logo } \\
\text { dari Cimory itu sendiri. } \\
\text { Penempatan logo terdapat } \\
\text { di tengah atas desain botol } \\
\text { dengan dasar warna logo } \\
\text { adalah warna botolnya } \\
\text { yang transparan sehingga } \\
\text { menggunakan warna dari } \\
\text { minuman yogurt itu } \\
\text { sendiri yang berwarna } \\
\text { pastel sehingga logo } \\
\text { mudah dikenali oleh } \\
\text { konsumen. }\end{array}$ & $\begin{array}{l}\text { Logo yang terpampang } \\
\text { pada kemasan adalah logo } \\
\text { dari Cimory itu sendiri. } \\
\text { Penempatan logo terdapat } \\
\text { di tengah atas desain botol } \\
\text { dengan dasar warna logo } \\
\text { berwarna merah sehingga } \\
\text { logo mudah dikenali oleh } \\
\text { konsumen. }\end{array}$ & $\begin{array}{l}\text { Logo yang terpampang pada } \\
\text { kemasan adalah logo dari } \\
\text { Cimory itu sendiri. } \\
\text { Penempatan logo terdapat di } \\
\text { tengah atas desain botol } \\
\text { dengan dasar warna logo } \\
\text { berwarna putih sehingga logo } \\
\text { mudah dikenali oleh } \\
\text { konsumen. }\end{array}$ \\
\hline Ilustrasi & $\begin{array}{l}\text { Ilustrasi yang digunakan } \\
\text { pada kemasan } \\
\text { menggunakan teknik } \\
\text { gabungan foto dan vector. } \\
\text { Foto yang ditampilkan } \\
\text { pada kemasan untuk } \\
\text { memperjelas varian rasa } \\
\text { yang ada pada kemasan. } \\
\text { Ilustrasi vector berupa } \\
\text { tekstur susu untuk } \\
\text { memperjelas bahwa } \\
\text { produk yang dijual adalah } \\
\text { produk olahan susu. Dan } \\
\text { juga menampilkan elemen } \\
\text { visual berupa corak hitam } \\
\text { putih yang menjadi ciri }\end{array}$ & $\begin{array}{l}\text { Ilustrasi yang digunakan } \\
\text { pada kemasan } \\
\text { menggunakan teknik } \\
\text { gabungan foto dan vector. } \\
\text { Foto yang ditampilkan pada } \\
\text { kemasan untuk } \\
\text { memperjelas varian rasa } \\
\text { yang ada pada kemasan. } \\
\text { Ilustrasi vector berupa } \\
\text { tekstur susu untuk } \\
\text { memperjelas bahwa produk } \\
\text { yang dijual adalah produk } \\
\text { olahan susu. Ilustrasi foto } \\
\text { nyata seperti buah } \\
\text { strawberry memberikan } \\
\text { penjelasan langsung }\end{array}$ & $\begin{array}{l}\text { Ilustrasi yang digunakan pada } \\
\text { kemasan menggunakan teknik } \\
\text { gabungan foto dan vector. Foto } \\
\text { yang ditampilkan pada } \\
\text { kemasan untuk memperjelas } \\
\text { varian rasa yang ada pada } \\
\text { kemasan. Ilustrasi vector } \\
\text { berupa tekstur susu untuk } \\
\text { memperjelas bahwa produk } \\
\text { yang dijual adalah produk } \\
\text { olahan susu. Dan juga } \\
\text { menampilkan elemen visual } \\
\text { berupa corak hitam putih yang } \\
\text { menjadi ciri khas motif kulit } \\
\text { sapi. }\end{array}$ \\
\hline
\end{tabular}

Mixed berry, Strawberry, Mixed berry, strawberry, Original blueberry, original ini umum dipakai oleh sesama produk minuman yogurt. Sederhana dan memiliki ukuran yang pas untuk digenggam.

\section{Logo yang terpampang dari Cimory itu sendiri. Penempatan logo terdapa logo mudah dikenali oleh} Ilustrasi yang digunakan pada kemasan menggunakan teknik gabungan foto dan vector Foto yang ditampilkan pada emasan untuk memperjelas bahwa produk yang dijual adalah produk nyata seperti buah penjelasan langsung 


\begin{tabular}{|c|c|c|c|}
\hline & khas motif kulit sapi. & $\begin{array}{l}\text { mengenai rasa produk } \\
\text { yogurt ini adalah rasa } \\
\text { strawberry }\end{array}$ & \\
\hline Tipografi & $\begin{array}{l}\text { Tipografi yang digunakan } \\
\text { pada kemasan ini adalah } \\
\text { jenis san serif pada tulisan } \\
\text { Yogurt Drink sehingga } \\
\text { memiliki tingkat } \\
\text { keterbacaan yang baik. } \\
\text { Ukuran yang digunakan } \\
\text { juga cukup baik. } \\
\text { Penggunaan warna pada } \\
\text { teks informasi produk } \\
\text { disesuaikan dengan tema } \\
\text { warna dari varian rasa. } \\
\text { Selain itu untuk informasi } \\
\text { nilai gizi dan barcode } \\
\text { menggunakan warna } \\
\text { hitam dengan warna latar } \\
\text { belakang putih untuk } \\
\text { memudahkan keterbacaan } \\
\text { teks. }\end{array}$ & $\begin{array}{l}\text { Tipografi yang digunakan } \\
\text { pada kemasan ini adalah } \\
\text { jenis san serif pada tulisan } \\
\text { Yogurt Drink sehingga } \\
\text { memiliki tingkat } \\
\text { keterbacaan yang baik. } \\
\text { Ukuran yang digunakan } \\
\text { juga cukup baik. } \\
\text { Penggunaan warna pada } \\
\text { teks nama produk } \\
\text { menyesuaikan dengan } \\
\text { warna biru tua dari logo } \\
\text { Cimory. Sedangkan } \\
\text { informasi umum } \\
\text { menggunakan warna merah } \\
\text { dari warna merah logo. } \\
\text { Selain itu untuk informasi } \\
\text { nilai gizi, komposisi dan } \\
\text { barcode menggunakan } \\
\text { warna hitam dengan warna } \\
\text { latar belakang putih untuk } \\
\text { memudahkan keterbacaan } \\
\text { teks. }\end{array}$ & $\begin{array}{l}\text { Tipografi yang digunakan pada } \\
\text { kemasan ini adalah jenis san } \\
\text { serif pada tulisan Yogurt Drink } \\
\text { sehingga memiliki tingkat } \\
\text { keterbacaan yang baik. Ukuran } \\
\text { yang digunakan juga cukup } \\
\text { baik. } \\
\text { Penggunaan warna pada teks } \\
\text { informasi produk disesuaikan } \\
\text { dengan tema warna dari varian } \\
\text { rasa. Selain itu untuk informasi } \\
\text { nilai gizi dan barcode } \\
\text { menggunakan warna hitam } \\
\text { dengan warna latar belakang } \\
\text { putih untuk memudahkan } \\
\text { keterbacaan teks. }\end{array}$ \\
\hline Layout & $\begin{array}{l}\text { Kemasan sudah disertai } \\
\text { dengan informasi lengkap } \\
\text { dan dikomposisi dengan } \\
\text { cukup baik. } \\
\text { Informasi yang tertera } \\
\text { pada kemasan meliputi } \\
\text { nama produk, daftar } \\
\text { bahan yang digunakan, } \\
\text { berat bersih atau isi } \\
\text { bersih, nama dan alamat } \\
\text { pihak yang memproduksi, } \\
\text { keterangan halal, tanggal, } \\
\text { bulan, dan tahun } \\
\text { kadaluarsa. Komposisi } \\
\text { diatur dengan alignment } \\
\text { center per sisi kemasan. }\end{array}$ & $\begin{array}{l}\text { Kemasan sudah disertai } \\
\text { dengan informasi lengkap } \\
\text { dan dikomposisi dengan } \\
\text { cukup baik. } \\
\text { Informasi yang tertera pada } \\
\text { kemasan meliputi nama } \\
\text { produk, daftar bahan yang } \\
\text { digunakan, berat bersih } \\
\text { atau isi bersih, nama dan } \\
\text { alamat pihak yang } \\
\text { memproduksi, keterangan } \\
\text { halal, tanggal, bulan, dan } \\
\text { tahun kadaluarsa. } \\
\text { Komposisi diatur dengan } \\
\text { alignment center per sisi } \\
\text { kemasan. }\end{array}$ & $\begin{array}{l}\text { Kemasan sudah disertai } \\
\text { dengan informasi lengkap dan } \\
\text { dikomposisi dengan cukup } \\
\text { baik. } \\
\text { Informasi yang tertera pada } \\
\text { kemasan meliputi nama } \\
\text { produk, daftar bahan yang } \\
\text { digunakan, berat bersih atau isi } \\
\text { bersih, nama dan alamat pihak } \\
\text { yang memproduksi, } \\
\text { keterangan halal, tanggal, } \\
\text { bulan, dan tahun kadaluarsa. } \\
\text { Komposisi diatur dengan } \\
\text { alignment center per sisi } \\
\text { kemasan. Untuk kemasan } \\
\text { sekunder komposisi disusun } \\
\text { secara simetris dengan } \\
\text { menggunakan keseimbangan } \\
\text { antara image dan informasi } \\
\text { produk. }\end{array}$ \\
\hline
\end{tabular}




\begin{tabular}{|c|c|c|c|}
\hline Pengaman & $\begin{array}{l}\text { Kemasan yang digunakan } \\
\text { cukup baik untuk } \\
\text { melindungi isi produk. } \\
\text { Kemasan yang digunakan } \\
\text { terbuat dari plastik PET } \\
\text { berukuran } 250 \text { ml. Tutup } \\
\text { pada botol juga disertai } \\
\text { segel sehingga cairan } \\
\text { yang terdapat pada botol } \\
\text { tidak bocor. }\end{array}$ & $\begin{array}{l}\text { Kemasan yang digunakan } \\
\text { cukup baik untuk } \\
\text { melindungi isi produk. } \\
\text { Bahan yang digunakan } \\
\text { adalah tetrapak dengan } \\
\text { sifatnya yang ringan tetapi } \\
\text { memiliki daya } \\
\text { ketahananyang baik } \\
\text { sehingga cairan tidak akan } \\
\text { bocor. }\end{array}$ & $\begin{array}{l}\text { Kemasan yang digunakan } \\
\text { cukup baik untuk melindungi } \\
\text { isi produk. Bahan PS bersifat } \\
\text { ringan tetapi memiliki daya } \\
\text { ketahanan yang baik sehingga } \\
\text { cairan tidak akan bocor. }\end{array}$ \\
\hline Ekonomi & $\begin{array}{l}\text { Kemasan menggunakan } \\
\text { botol plastik khusus } \\
\text { minuman sekali pakai } \\
\text { namun tetap ekonomis } \\
\text { dalam perhitungan biaya } \\
\text { produksi. }\end{array}$ & $\begin{array}{l}\text { Kemasan menggunakan } \\
\text { tetrapak khusus minuman } \\
\text { sekali pakai namun tetap } \\
\text { ekonomis dalam } \\
\text { perhitungan biaya produksi. }\end{array}$ & $\begin{array}{l}\text { Kemasan menggunakan } \\
\text { kemasan plastik khusus } \\
\text { minuman sekali pakai namun } \\
\text { tetap ekonomis dalam } \\
\text { perhitungan biaya produksi. }\end{array}$ \\
\hline Distribusi & $\begin{array}{l}\text { Kemasan yang digunakan } \\
\text { memudahkan dalam } \\
\text { pendistribusian produk. } \\
\text { Kemasan dirancang untuk } \\
\text { tidak menyulitkan } \\
\text { peletakan di rak ataupun } \\
\text { tempat pemajangan } \\
\text { produk. }\end{array}$ & $\begin{array}{l}\text { Kemasan yang digunakan } \\
\text { memudahkan dalam } \\
\text { pendistribusian produk. } \\
\text { Kemasan dirancang untuk } \\
\text { tidak menyulitkan } \\
\text { peletakan di rak ataupun } \\
\text { tempat pemajangan produk. }\end{array}$ & $\begin{array}{l}\text { Menggunakan kemasan } \\
\text { sekunder untuk memudahkan } \\
\text { dalam pendistribusian produk. } \\
\text { Kemasan dirancang untuk } \\
\text { tidak menyulitkan peletakan di } \\
\text { rak ataupun tempat } \\
\text { pemajangan produk }\end{array}$ \\
\hline Komunikasi & $\begin{array}{l}\text { Kemasan Cimory ini juga } \\
\text { sudah cukup baik dari } \\
\text { segi komunikasi. } \\
\text { Kemasan cukup } \\
\text { mencerminkan citra } \\
\text { produk, mudah dipahami } \\
\text { dan diingat oleh } \\
\text { pelanggan. }\end{array}$ & $\begin{array}{l}\text { Kemasan Cimory ini juga } \\
\text { sudah cukup baik dari segi } \\
\text { komunikasi. Kemasan } \\
\text { cukup mencerminkan citra } \\
\text { produk, mudah dipahami } \\
\text { dan diingat oleh pelanggan. }\end{array}$ & $\begin{array}{l}\text { Kemasan Cimory ini juga } \\
\text { sudah cukup baik dari segi } \\
\text { komunikasi. Kemasan cukup } \\
\text { mencerminkan citra produk, } \\
\text { mudah dipahami dan diingat } \\
\text { oleh pelanggan. }\end{array}$ \\
\hline Ergonomi & $\begin{array}{l}\text { Kemasan memiliki faktor } \\
\text { ergonomi yang baik. } \\
\text { Kemasan memiliki ukuran } \\
\text { yang mudah untuk } \\
\text { dipegang, dibawa dan } \\
\text { diambil. Selain itu } \\
\text { kemasan juga cukup } \\
\text { mudah untuk dibuka. }\end{array}$ & $\begin{array}{l}\text { Kemasan memiliki faktor } \\
\text { ergonomi yang baik. } \\
\text { Kemasan memiliki ukuran } \\
\text { yang mudah untuk } \\
\text { dipegang, dibawa dan } \\
\text { diambil. Selain itu kemasan } \\
\text { juga cukup mudah untuk } \\
\text { dibuka. }\end{array}$ & $\begin{array}{l}\text { Kemasan memiliki faktor } \\
\text { ergonomi yang baik. Kemasan } \\
\text { memiliki ukuran yang mudah } \\
\text { untuk dipegang, dibawa dan } \\
\text { diambil. Selain itu kemasan } \\
\text { juga cukup mudah untuk } \\
\text { dibuka. }\end{array}$ \\
\hline Identitas & $\begin{array}{l}\text { Identitas produk dapat } \\
\text { dengan mudah dikenali } \\
\text { melalui kemasan. Warna } \\
\text { yang digunakan cukup } \\
\text { mencolok serta logo } \\
\text { ditampilkan di bagian atas } \\
\text { dengan ukuran yang } \\
\text { cukup besar. }\end{array}$ & $\begin{array}{l}\text { Identitas produk dapat } \\
\text { dengan mudah dikenali } \\
\text { melalui kemasan. Warna } \\
\text { yang digunakan cukup } \\
\text { mencolok serta logo } \\
\text { ditampilkan di bagian atas } \\
\text { dengan ukuran yang cukup } \\
\text { besar. }\end{array}$ & $\begin{array}{l}\text { Identitas produk dapat dengan } \\
\text { mudah dikenali melalui } \\
\text { kemasan. Warna yang } \\
\text { digunakan cukup mencolok } \\
\text { serta logo ditampilkan di } \\
\text { bagian atas dengan ukuran } \\
\text { yang cukup besar. }\end{array}$ \\
\hline
\end{tabular}




\begin{tabular}{|c|c|c|c|c|}
\hline & Promosi & $\begin{array}{l}\text { Dari segi promosi, } \\
\text { kemasan telah } \\
\text { mempromosikan produk } \\
\text { dengan baik. } \\
\text { Menyertakan ilustrasi } \\
\text { yang dapat membedakan } \\
\text { varian rasa dengan jelas. }\end{array}$ & $\begin{array}{l}\text { Dari segi promosi, kemasan } \\
\text { telah mempromosikan } \\
\text { produk dengan baik. } \\
\text { Menyertakan ilustrasi yang } \\
\text { dapat membedakan varian } \\
\text { rasa dengan jelas. }\end{array}$ & $\begin{array}{l}\text { Dari segi promosi, kemasan } \\
\text { telah mempromosikan produk } \\
\text { dengan baik. Menyertakan } \\
\text { ilustrasi yang dapat } \\
\text { membedakan varian rasa } \\
\text { dengan jelas. }\end{array}$ \\
\hline & Lingkungan & $\begin{array}{l}\text { Ramah lingkungan karena } \\
\text { mudah terurai }\end{array}$ & $\begin{array}{l}\text { Ramah lingkungan karena } \\
\text { mudah terurai }\end{array}$ & $\begin{array}{l}\text { Ramah lingkungan karena } \\
\text { mudah terurai }\end{array}$ \\
\hline 6 & Simpulan & $\begin{array}{l}\text { Target dari produk ini } \\
\text { dominan untuk wanita } \\
\text { sehingga kemasan } \\
\text { didesain lebih feminin } \\
\text { dengan menekankan } \\
\text { bentuk kemasan yang } \\
\text { lebih ramping dan } \\
\text { penggunaan warna yang } \\
\text { dominan warna pastel. } \\
\text { Selain itu ukuran } \\
\text { minuman yang cukup } \\
\text { besar yaitu } 250 \text { ml untuk } \\
\text { mendukung gaya hidup } \\
\text { sehat dengan } \\
\text { mengonsumsi minuman } \\
\text { yogurt dalam jumlah yang } \\
\text { cukup dalam sehari. }\end{array}$ & $\begin{array}{l}\text { Target dari produk ini } \\
\text { untuk kalangan umum usia } \\
\text { produktif kelas middle } \\
\text { updengan kemasan didesain } \\
\text { secara minimalis dengan } \\
\text { ukuran sedang yaitu } 200 \mathrm{ml} \\
\text { sehingga dapat praktis } \\
\text { dibawa kemana saja. }\end{array}$ & $\begin{array}{l}\text { Target dari produk ini untuk } \\
\text { kalangan umum segmen } \\
\text { keluarga dari usia dini hingga } \\
\text { usia dewasa dengan kemasan } \\
\text { didesain secara minimalis } \\
\text { dalam ukuran yang kecil. }\end{array}$ \\
\hline
\end{tabular}

\section{SIMPULAN}

Berdasarkan analisis yang dilakukan, dapat disimpulkan bahwa bahan dari kemasan Cimory memiliki daya tarik visual yang baik karena sudah mempertimbangkan dan daya tarik praktis yang tergolong baik. Desain kemasan yang terdapat pada produk Cimory disesuaikan dengan target audience. Dari sisi visual, kemasan ini telah berhasil menarik perhatian dengan konsep yang berbeda namun identitas produk Cimory tetap dapat terkomunikasikan dengan baik. Sedangkan dari sisi fungsional, secara keseluruhan kemasan produk minuman Yogurt Cimory telah dipertimbangkan secara baik dari sisi kualitas, bentuk, ukuran dan porsi yang pas untuk kebutuhan konsumen.

Peneliti berharap di masa yang akan datang akan banyak bermunculan seri kemasan baru yang unik dengan ide-ide kreatif untuk memberikan tampilan dan warna baru pada industri pengemasan produk minuman di Indonesia.

\section{DAFTAR PUSTAKA}

Calver, Giles. 2007. What is Packaging Design. Singapore: Page One Publishing Private Limited.

Cenadi, Christine Suharto. 1999. Elemenelemen dalam Desain Komunikasi Visual. Jakarta: Nirmana.

Holtzschue, L. (2012). Understanding color: an introduction for designers. John Wiley \& Sons.

Julianti, Sri. 2014. The Art of Packaging. Jakarta: PT Gramedia Pustaka Utama. 
Klimchuk, Marianne dan Sandra A. Krasovec. 2007. Desain Kemasan. Jakarta: Erlangga

Pujiriyanto. 2005. Desain Grafis Komputer. Yogyakarta: CV Andi Offset.
Porter, Michael E. 1998. From Competitive Advantage to Corporate Strategy. Harvard Business Review.

Tamime, a. Y., \& Robinson, R. K. (2007). 1. Historical Background. In Tamime and Robinson's Yoghurt - Science and Technology (Vol. 25, pp. 1-12). https://doi.org/10.1159/000331070 